\title{
MULTIFUNCTIONAL NANOCOMPOSITE MATERIALS
}

\author{
A Progress Report of Research Effort \\ Under Grant Numbered DE-FG02-91ER45204 \\ During the First Year of Support
}

and
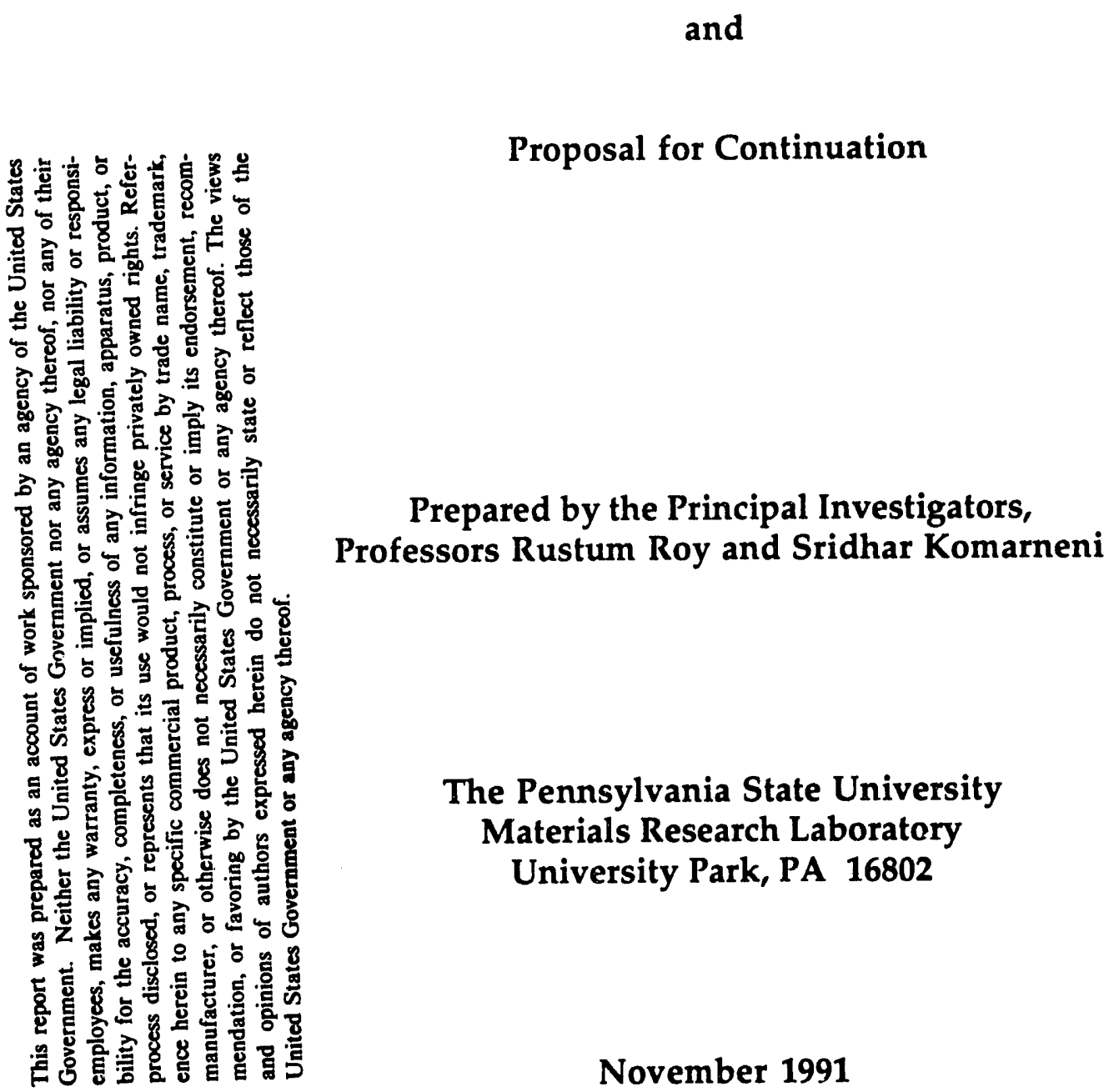

November 1991

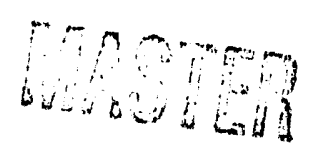


1.

\section{MULTIFUNCTIONAL NANOCOMPOSITE MATERIALS}

\section{Table of Contents}

Rationale for the Research

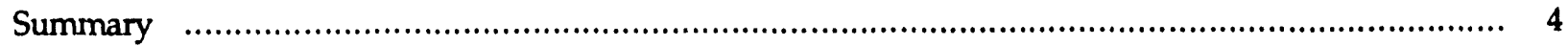

Progress Report

Curnulative List of Publications and Presentations 


\section{RATIONALE FOR THE RESEARCH}

The main objective of this research is to examine the low temperature nanocomposite route in the synthesis of multifunctional materials using twodimensional clays as hosts. While there is a great deal of research on the synthesis of high-temperature glasses and ceramics, there is but little research on new lowtemperature materials. Yet the commercial value of the latter is several orders of magnitude larger, and the opportunity for genuine scientific innovation is also much greater. The flexible two-dimensional clays have high chemical reactivity which can be used in the design and synthesis of new materials. The proposal, and now successfully demoristrated approach, to achieve multifunctional nanocomposite materials will undoubtedly have a significant bearing on low temperature materials research. 


\section{- PROGRESS REPORT}

\section{Summary}

After about eight months of the initiation of the new project, we have made a significant advance in the design and synthesis of novel nanocomposite materials. These novel nanocomposites are nanometal intercalated clays which have been prepared by a low temperature route. A layered vanadium pentaoxide gel has been made hydrothermally and its cation exchange properties have been measured. Several pillared clays have also been synthesized and characterized for further studies. In this period, one patent application has been filed, several papers published and one paper presented. Several other papers are in progress. The details of the progress made thus far are given below under separate headings.

A. Metal Intercalated Clays. P. B. Malla, P. Ravindranathan, S. Komarneni and R. Roy

PSU Invention Disclosure No. 91-1042

We have developed a low temperature polyol process which led to the deposition of nanometal particles between the interlayers of montmorillonite. Earlier attempts by others to produce intercalated zero-valent transition-metal particles in layer silicates, by hydrogen reduction for example, failed: The layers tend to collapse, sometimes followed by deposition of metal particles on the external surfaces. Here we have successfully intercalated copper metal clusters of $4-5 \AA$ in montmorillonite by in situ reduction of $\mathrm{Cu}^{2+}$ ions using ethylene glycol. These metal-cluster intercalates were stable up to at least $500^{\circ} \mathrm{C}$. The clusters prop the silicate layers apart, much as metal oxides do in pillared clays, and may thus be able to introduce unique catalytic product selectivity through a molecular sieving effect similar to that in cluster-loaded zeolites. As metal clusters of these dimensions behave very differently from the bulk metal, intercalates of this sort may prove to be versatile catalysts.

\section{B. Hydrothermal Synthesis, Cesium Selectivity and Water Sorption Property of $\mathrm{V}_{2} \mathrm{O}_{5} \cdot \mathrm{nH}_{2} \mathrm{O}$ Gel}

Layered vanadium pentoxide gels, analogous to montmorillonite layered silicate were synthesized under hydrothermal conditions at $200^{\circ} \mathrm{C}$. The gel was characterized by $\mathrm{x}$-ray diffraction and thermal analyses and electron microscopy. Water sorption isotherm of $\mathrm{V}_{2} \mathrm{O}_{5}$ gel indicated that the gel initially has micropores or cavities commensurate with the size of water molecules. At higher relative pressures of water, steps in the sorption isotherm appeared indicating the montmorillonite type layer structure which expands and accommodates at least two layers of water molecules in between the layers. This gel is stable in aqueous media 
and hence could be used as an ion exchanger for several alkali, alkaline earth and transition metal cations. The gel exhibited high selectivity for cesium ion $\left(\mathrm{K}_{\mathrm{d}}=226-\right.$ 981 ) in the presence of highly concentrated solutions of metal (M) cations such as $\mathrm{Li}^{+}, \mathrm{Na}^{+}, \mathrm{K}^{+}, \mathrm{Mg}^{2+}, \mathrm{Ca}^{2+}, \mathrm{Ba}^{2+}$, and $\mathrm{Sr}^{2+}(\mathrm{M} / \mathrm{Cs}$ equivalent ratio $=250)$. Its cesium uptake and selectivity was investigated in detail at room temperature. This property could be useful in the separation of Cs from radioactive waste solutions or naturally occurring brines. This layered phase can also be used as a host just as in the case of montmorillonite for intercalation.

\section{Synthesis of Pillared Clays}

We have synthesized and characterized by powder $x$-ray diffraction several pillared clays using montmorillonite, beidellite, nontronite and hectorite as hosts and hydroxy polymeric cations of $\mathrm{Al}, \mathrm{Zr}$ and $\mathrm{Ti}$ as guests. These will be investigated in the coming year for cation separation, waste disposal, catalysis, etc. The stability of the intercalated organic luminescent hosts such as rhodamine, pyronine, etc., in these nanocomposites will be explored. 


\section{CUMULATIVE LIST OF PUBLICATIONS AND PRESENTATIONS RESULTING FROM CURRENT GRANT}

$\underline{1985-1987}$

1. S. Komarneni, R. Roy and D.M. Roy, "Pseudomorphism in Xonotlite and Tobermorite with $\mathrm{Co}^{2+}$ and $\mathrm{Ni}^{2+}$ Exchange for $\mathrm{Ca}^{2+}$ at 2500C," Cem. Concr. Res. 16:47-58 (1986).

2. S. Komarneni and R. Roy, "Topotactic Route to Synthesis of Novel Hydroxylated Phases: I. Trioctahedral Micas," Clay Minerals 21:125-131 (1986).

3. S. Komarneni and R. Roy, "Low Temperature Materials for Waste Disposal: I. Hydroxylated Phases," Abstracts, The American Ceramic Society 88th Annual Meeting, Chicago, IL, p. 516 (1986).

4. S. Komarneni and R. Roy, "Cesium Exchange and Selective Properties of g-Titanium Phosphate," Abstracts, The American Ceramic Society 88th Annual Meeting, Chicago, IL, p. 517 (1986).

5. S. Komarneni, E. Breval, D.M. Roy and R. Roy, "Synthesis and Characterization of a $12.6 \AA$ Calcium Silicate Hydrate," Cem. Concr. Res. 16:580-586 (1986).

6. S. Komarneni, M. Miyake and R. Roy, "Clay and Zeolite Analogs in Calcium Silicates: Cation Exchange Properties of [Al+Na]-Substituted Tobermorites," Abstracts, 23rd Annual Meeting of the Clay Minerals Society in Jackson, MS, p. 58 (1986).

7. S. Komarneni and R. Roy, "Low Temperature Materials for Waste Disposal: I. Hydroxylated Phases," in Advances in Ceramics, Vol. 20: Nuclear Waste Management II (Ed. D.E. Clark), The American Ceramic Society, Columbus, OH, pp. 197-204 (1987).

8. S. Komarneni R. Roy, "Cesium Exchange, Selectivity and Fixation Properties of g-Titanium Phosphate," in Advances in Ceramics, Vol. 20: Nuclear Waste Management II (Ed. D.E. Clark), The American Ceramic Society, Columbus, OH, pp. 205-211 (1987).

9. M. Miyake, S. Komarneni and R. Roy, "Reactions of Wollastonite and Xonotlite with $\mathrm{NH}_{4} \mathrm{H}_{2} \mathrm{PO}_{4}$ and $\mathrm{H}_{3} \mathrm{PO}_{4}$, " Zeitschrift fur Kristallographie 179:383-393 (1987).

10. S. Komarneni and R. Roy, "Low Temperature Materials for Waste Disposal," Abstracts, The American Ceramic Society 89th Annual Meeting, Pittsburgh, FA, p. 284 (1987).

11. S. Komarneni and R. Roy, "Phillipsite Alteration in Hydrothermal Brines," Mat. Res. Bull. 22:1179-1186 (1987).

\section{$\underline{1988-1989}$}

12. S. Komarneni, E. Breval, D.M. Roy and R. Roy, "Reactions of Some Calcium Silicates with Metal Cations," Cem. Concr. Res. 18:204-220 (1988).

13. M. Miyake, S. Komarneni and R. Roy, "Dealumination of Zeolites and Clay Minerals with $\mathrm{SiCl}_{4}$ or $\left(\mathrm{NH}_{4}\right)_{2} \mathrm{SiF}_{6}$," Clay Minerals 22:367-371 (1988).

14. S. Komarneni and R. Roy, "Cesium Selective Ion Sieve Made by Topotactic Leaching," Science 239:1286-1288 (1988). 
15. M. Miyake, S. Komarneni and R. Roy, "Immobilization of $\mathrm{Pb}^{2+}, \mathrm{Cd}^{2+}, \mathrm{Sr}^{2+}$ and $\mathrm{Ba}^{2+}$ Ions Using Calcite and Aragonite," Cem. Concr. Res. 18:485-490 (1988).

16. S. Komarneni, "Mechanisms of Polygorskite and Sepiolite Alteration as Deduced from SolidState ${ }^{27} \mathrm{Al}$ and ${ }^{29} \mathrm{Si}$ Nuclear Magnetic Resonance Spectroscopy," Clays and Clay Minerals 37:469473 (1989).

17. S. Komarneni and R. Roy, "Process for Cesium Decontamination and Immobilization," U.S. Patent No. $4,808,318$ (1989).

18. W.J. Paulus, S. Komarneni and R. Roy, "Selective Ion Exchange of a New Synthetic Highly Charged Mica," Abstracts, 92nd Annual Meeting of the American Ceramic Society in Indianapolis, IN, p. 112 (1989).

19. W.J. Paulus, S. Komarneni and R. Roy, "A New and Highly Effective Method for Synthesizing Highly Charged Sodium Phlogopite Mica," PSU Invention Disclosure No. $89-927$ (1989).

$\underline{1990-1991}$

20. X. Ren, S. Komarneni and D.M. Roy, "Novel CsAl ${ }_{2} \mathrm{PO}_{6}$ of Pollucite Structure: Synthesis and Characterization," Mat. Res. Bull. 25:665-670 (1990).

21. P. Ravindranathan, P. B. Malla, S. Komarneni and R. Roy, "Preparationof Metal Supported Montmorillonite Catalyst: A New Approach," Catalysis Letters 6:401-408 (1990).

22. W.J. Paulus, "Highly Charged Sodium Phlogopite Mica: Synthesis, Characterization and Cation Exchange Properties," M.S. Thesis, The Pennsylvania State University, University Park, 123 pp. (1990).

23. L. Pach, Z. Hrabe, S. Komarneni and R. Roy, "Controlled Crystallization of Vaterite from Viscous Solutions of Organic Colloids," I. Mat. Res. 5:2928-2932 (1990).

24. Z. Hrabe, S. Komarneni, P. Malla, V. Srikanth and R. Roy, "Pillared Montmorillonite Clay as a Raw Material for the Synthesis of $\beta^{\prime}$-Sialon," L. Mat. Sci. (in press).

25. O. P. Shrivastava, S. Komarneni and P. Malla, "Hydrothermal Synthesis, Cesium Selectivity and Water Sorption Property of $\mathrm{V}_{2} \mathrm{O}_{5} \cdot \mathrm{nH}_{2} \mathrm{O}$ Gel, Mat. Res. Bull. 26:357-366 (1991).

26. P.B. Malla, P. Ravindranathan, S. Komarneni and R. Roy, "Intercalation of Copper Metal Clusters in Montmorillonite," Nature 351:555-557 (1991).

27. S. Komarneni, W.B. Paulus and R. Roy, "Novel Swelling Mica: Synthesis, Characterization and Cation Exchange," in New Developments in Ion Exchange (Eds. M. Abe, T. Kataoka and T. Suzuki), Proc. of Intl. Conference on Ion Exchange, Publ. by Kodansha, Tokyo, Japan, p. 51-56 (1991).

28. P. B. Malla, P. Ravindranathan, S. Komarneni, E. Breval and R. Roy, "Reduction of Hydroxycopper Acetate Interlayers in Montmorillonite by Polyol Process: A New Approach for Preparation of Metal Intercalated and Supported Catalysts," L. Mat. Chem. (submitted). 


\section{SUMMARY OF PROPOSED RESEARCH}

In the present grant we have already made a substantial advancee in the design and synthesis of new metal intercalated clay nanocomposites using twodimensional clays. By using a low temperature reduction process, we have been able to intercalate copper metal clusters of 4 to $5 \AA$ in montmorillonite. We will continue to pursue this fruitful line of research during the second year of the project.

We propose to:

1. Continue the synthesis and characterization of nanocomposite materials based on two-dimensional layer structures;

2. Continue the investigation of these nanocomposites for cation separation, waste disposal and possibly catalysis;

3. Initiate the investigation of the effect of inorganic crystal field on the thermal and optical properties of organic phases in nanocomposites.

\section{Task 1. Design, Synthesis and Characterization of Nanocomposites}

We have already synthesized and characterized several nanocomposites of clays, i.e., pillared clays using montmorillonite, beidellite, nontronite and hectorite and hydroxy polymeric cations of $\mathrm{Al}, \mathrm{Zr}, \mathrm{Ti}$. We will continue the synthesis studies with sauconite and saponite swelling clays with the above pillaring cations. In addition, we will also prepare pillared clays with mixed pillars such as $\mathrm{SiO}_{2}-\mathrm{TiO}_{2}$, $\mathrm{SiO}_{2}-\mathrm{Al}_{2} \mathrm{O}_{3}$ and $\mathrm{SiO}_{2}-\mathrm{Fe}_{2} \mathrm{O}_{3}$. The role of all these nanocomposites in cation separation, waste disposal and stabilization of organic phases will be investigated under Tasks 2 and 3. We will continue to make and characterize the novel metalintercalated clays using montmorillonite and metals such as $\mathrm{Ni}, \mathrm{Co}, \mathrm{Pt}$ and $\mathrm{Pd}$. The determination of the role of these nanocomposites in catalytic reactions have already been initiated with our colleagues in Chemical Engineering and Combustion Laboratory and will be continued.

\section{Task 2. Investigation of the Nanocomposites for Cation Separation and Waste Disposal}

The pillared clays with ditferent interlayer spacings will be equilibrated with ions such as $\mathrm{UO}_{2}^{2+}, \mathrm{Li}^{+}, \mathrm{Mg}^{2+}$ in a background solution containing $\mathrm{Na}^{+}, \mathrm{Ca}^{2+}$ and $\mathrm{K}^{+}$ to determine their selectivity. Preliminary studies with organic toxicants such as chlorophenols, polychlorinated biphenyls (PCBs, to determine their selectivity on the pillared clays will be started during this second year. 
Task 3. Effect of Inorganic Crystal Field on Thermal Stability and Optical Properties of Organic Phases

The thermal stability of the organic phases such as rhodamine, pyronine, etc., after their intercalation in swelling clays such as montmorillonite, beidellite, nontronite, saponite, sauconite and hectorite and their pillared counterparts will be investigated. Preliminary studies of the effects on the luminescence of the above organics through compositing will be explored. 
DATE FILMED 12118192 
